Elsevier Editorial System(tm) for Tourism Management

Manuscript Draft

Manuscript Number: JTMA-D-07-00101

Title: Exploring the spatial patterns of car-based tourist travel in Loch Lomond and Trossachs National Park, Scotland

Article Type: Research Paper

Keywords: GIS, Loch Lomond and Trossachs National Park, Scotland, Itinerary mapping, Car

Corresponding Author: Steve Page,

Corresponding Author's Institution: University of Stirling

First Author: Steve Page

Order of Authors: Steve Page; Joanne Connell

Abstract: Car transport is a vital element in tourism yet there is a surprising neglect of the role of the car on tourism travel patterns, behaviour and activities. This exploratory paper focuses on the use of itinerary mapping as a useful methodology to identify how aggregate travel flow as well as more detailed individual itineraries can be mapped and understood using a Geographical Information system (GIS). The focus of this exploratory research is the Loch Lomond and the Trossachs National Park, Scotland first National Park established in 2002, where a variety of itinerary patterns are revealed through a map-based questionnaire of visitors using National Park roads ( $n=749)$. The implications for planning and policy initiatives are discussed. 


\section{Table 1: Key Characteristics of LLTNP}

- The Park's boundary includes a total of 39 miles of coastline around the three sea lochs, Loch Long, Loch Goil and the Holy Loch.

- Loch Lomond is the largest area of freshwater in Britain, covering an area of 71 square kilometers (27.45 square miles).

- The Park contains the largest conventional hydroelectric power station in the UK at Loch Sloy.

- Water from the National Park has been used to provide drinking water to the nearby Glasgow conurbation since the 1850s.

- Farming is the major land use in the Park with registered agricultural land accounting for around $55 \%$ of the area.

- Almost all (98\%) of the Park's agricultural land is classified as an Agriculturally Less Favoured Area.

- Important remnants of ancient Caledonian pinewoods survive at Glen Falloch and Strathfillan, the most southerly examples in Scotland.

- Two thirds of the Park's woodland is coniferous.

- The Loch Lomond woodlands are one of the largest areas of semi-natural woodlands in Britain.

- Eight Special Areas of Conservation (SAC) designated to main tain or restore natural habitats and wild spaces, and one Special Protection Area (SPA) at Loch Lomond designated for the protection of rare or vulnerable birds

- There are two National Nature Reserves in the Park: Loch Lomond and Ben Lui.

- Approximately 184 UK Biodiversity Action Plan species of Conservation Concern have been identified in the National Park.

- Native roe and red deer, present in Britain since the end of the last ice age are found in much of the Park. There are also small groups of non-native fallow and occasional incursions of male Sika deer.

\section{VISITORS}

- A survey of visitor patterns to the Park between 2001 and 2003 reveals that the highest number of visits is in August and the lowest is in February.

- Surveys show that Loch Lomond and the Trossachs areas of the Park are the mostheavily visited.

- Day visitors accounted for $61 \%$ of all vis its to the Park in 2002. 
- A recent visitor survey (2003) surveyed 3,000 visitors and found that:

$\circ$ the things that they liked most about the Park are the scenery, peacefulness and easy going pace of life.

- They are more likely to be over 35 . Younger visitors are more inclined to visit the Loch Lomond area.

- $63 \%$ were from Scotland, $25 \%$ were from the rest of the UK and $12 \%$ from overseas.

- The most regular type of accommodation used was hotels (27\%). $24 \%$ stayed in a bed and breakfast or guest house.

- $85 \%$ of those surveyed visited the area by car. $69 \%$ said that they would spend time sightseeing, $25 \%$ said they would do some low level walking (less than two miles) $19 \%$ said they would do some hillwalking $17 \%$ said they would visit heritage attractions, and $12 \%$ said they would partake in active pursuits.

Source: LLTNP (2005a)

Table 2 Most Popular Reasons for Stopping (based on stops 1-5)

\begin{tabular}{|l|l|}
\hline & Percentage of stor \\
\hline Refreshments/picnic & 24.6 \\
\hline Active pursuit & 20.3 \\
\hline Sightseeing & 12.4 \\
\hline Short walk & 10.4 \\
\hline Shopping & 7.8 \\
\hline Utility break & 6.9 \\
\hline Visit attraction & 6.8 \\
\hline Other & 10.9 \\
\hline
\end{tabular}

Table 3 Reasons for Stopping According to Destination of Visitors

\begin{tabular}{|l|l|l|}
\hline & $\begin{array}{l}\text { Percentage of respondents ju } \\
\text { passing through LLTNP en } \\
\text { route to another destination }\end{array}$ & $\begin{array}{l}\text { Percentage of responden ts } \\
\text { specifically visiting LLTNP }\end{array}$ \\
\hline Refreshments/picnic & 57.3 & 33.2 \\
\hline Walk & 18.7 & 17.9 \\
\hline Sightseeing & 17.9 & 24.8 \\
\hline Shopping & 9.3 & 17.2 \\
\hline Visit attraction & 4.1 & 18.2 \\
\hline Active pursuit & 28.5 & 42.0 \\
\hline
\end{tabular}




\begin{tabular}{|l|l|l|}
\hline Utility break & 9.8 & 14.1 \\
\hline Other & 11.0 & 25.7 \\
\hline
\end{tabular}

Table 4 Percentage of Visitors Engaging in Particular Activities at Locations

\begin{tabular}{|l|l|l|ll|l|l|}
\hline & Aberfoyle & Balmaha & Balloch & Callander & Luss & Tarbet \\
\hline Refreshments & 25 & 31 & 25 & 41 & 44 & 27 \\
\hline Short walk & 8 & 12 & 5 & 13 & 11 & 18 \\
\hline Sightseeing & 17 & 38 & 9 & 8 & 7 & 9 \\
\hline Shopping & 10 & 8 & 11 & 5 & 3 & 0 \\
\hline Visit attraction & 6 & 4 & 3 & 1 & 3 & 0 \\
\hline Active pursuit & 10 & 8 & 17 & 17 & 15 & 21 \\
\hline Utility break & 6 & 0 & 11 & 7 & 6 & 9 \\
\hline Other & 17 & 0 & 14 & 7 & 11 & 15 \\
\hline
\end{tabular}


Figure 1: Itine rary Types

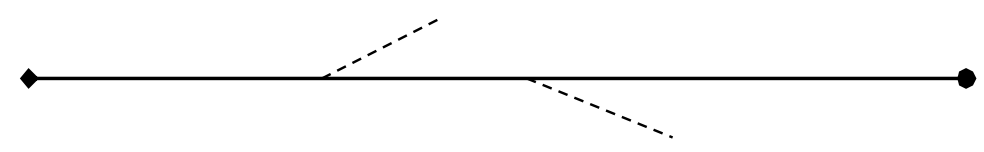

Single destination, with or without side trips

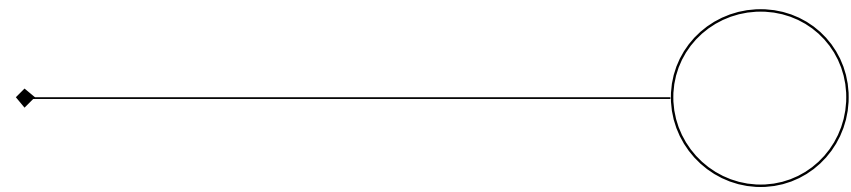

Transit leg and circle tour at a destination (transport modes may vary)

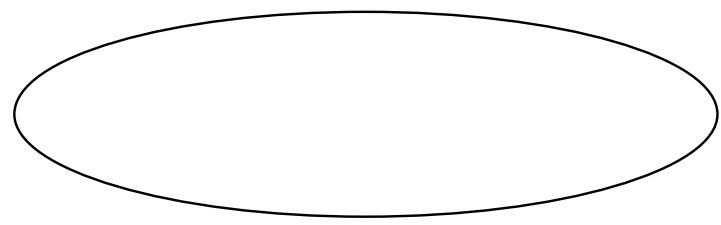

Circle tour with or without multiple access, egress points; different itinerary styles possible at different destination areas (transport mode may vary)

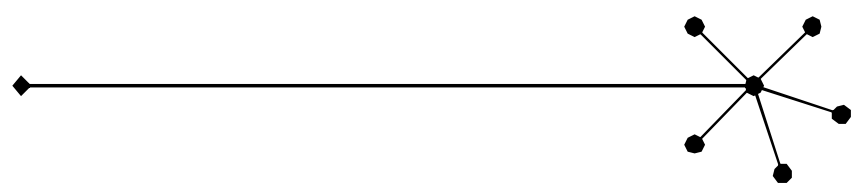

Hub-and-spoke style

(from home community or destination area)

(Source: McKercher and Lew 2004) 
Figure 2 Transit and Touring Components of an Itine rary

\begin{tabular}{|l|l|}
\hline Transit component & Destination touring component \\
\hline Return by same route & Single destination \\
\hline One way (either to or from destination & \\
\hline area)
\end{tabular}

Source: McKercher and Lew (2004) 
Figure 3 The Process of Route Analysis

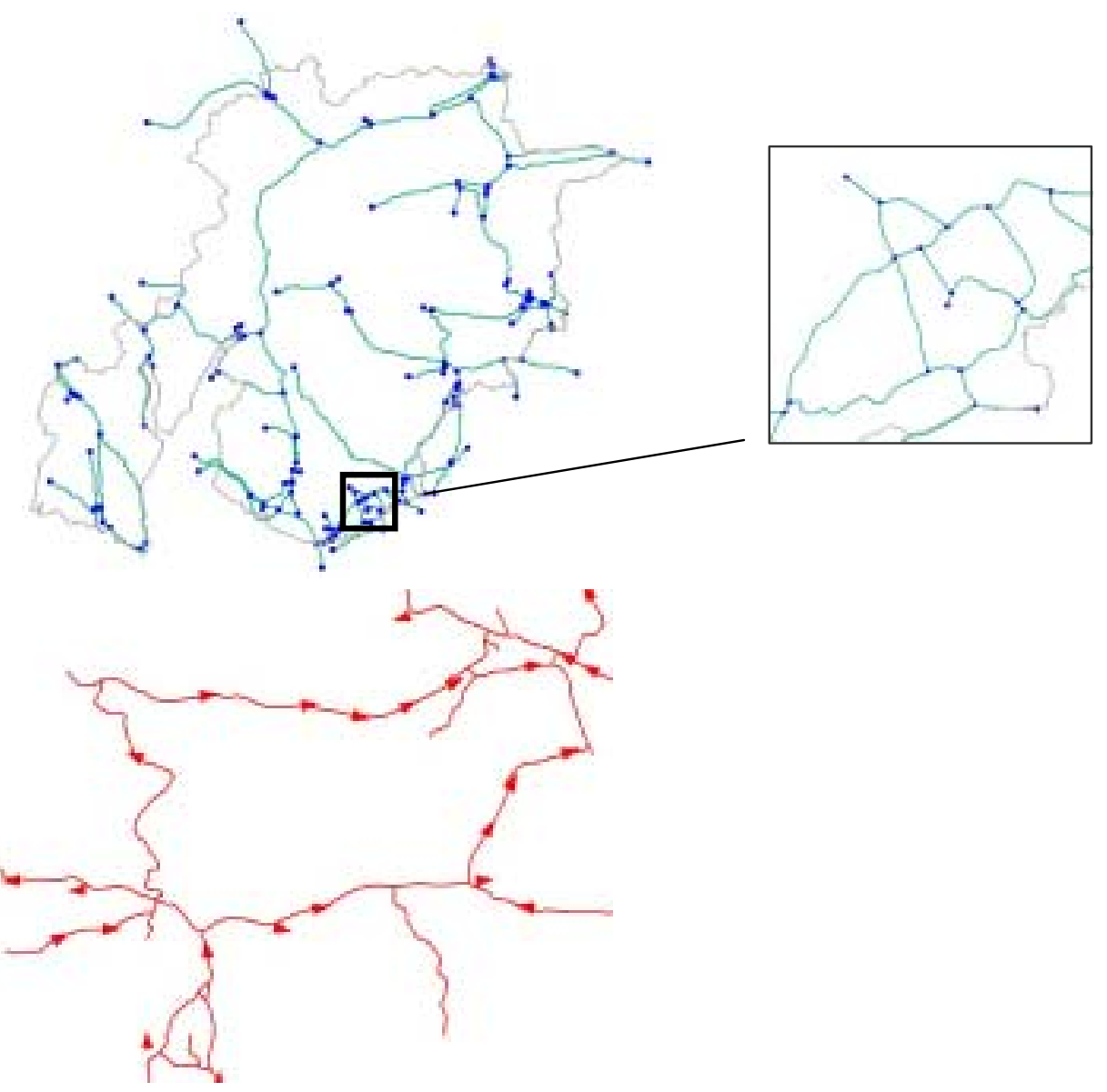


Figure 4 Aggregate Traffic Flow

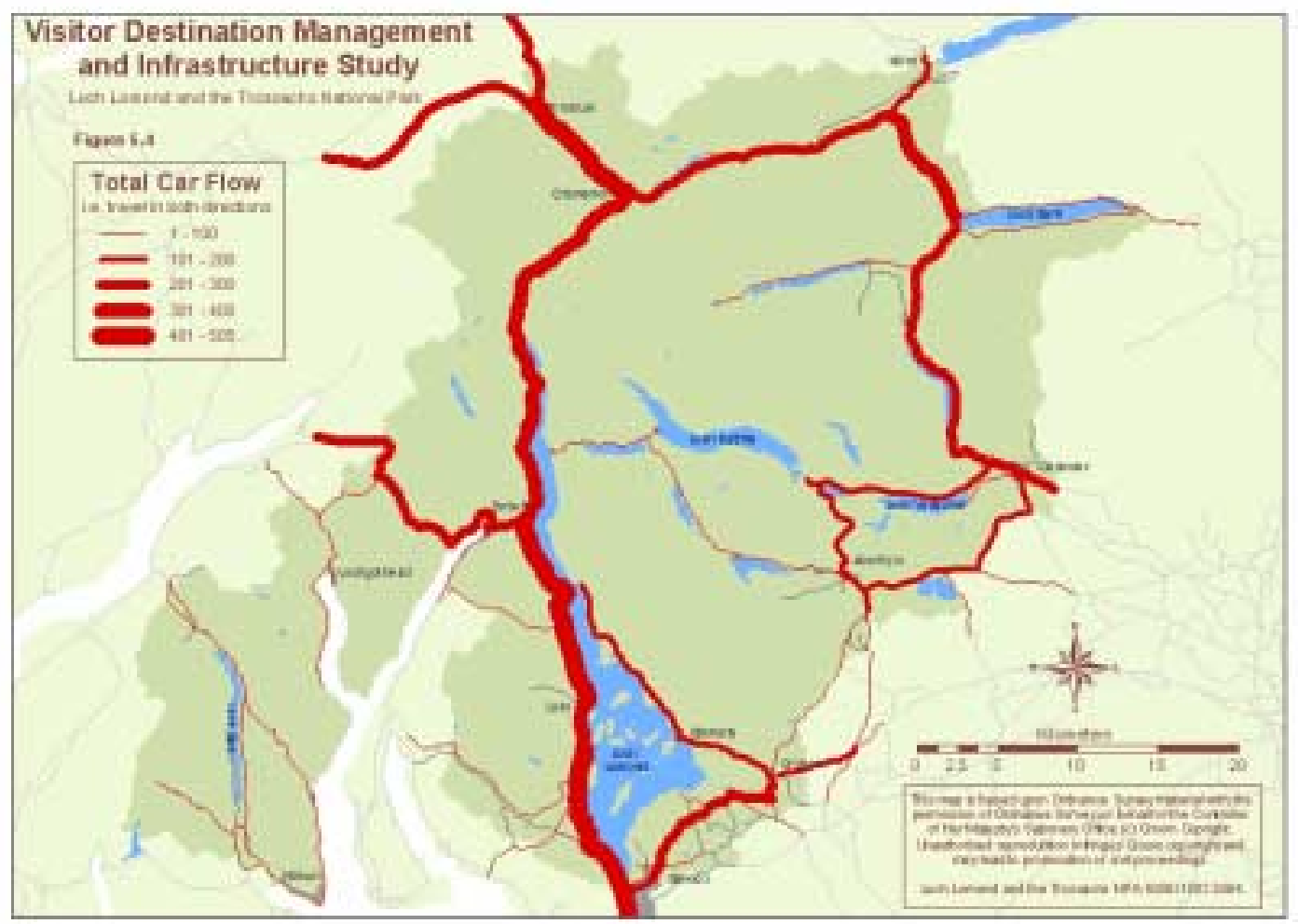

Source: (C) Loch Lomond and Trossachs National Park Authority (2004) 
Figure 5 Northbound Flow

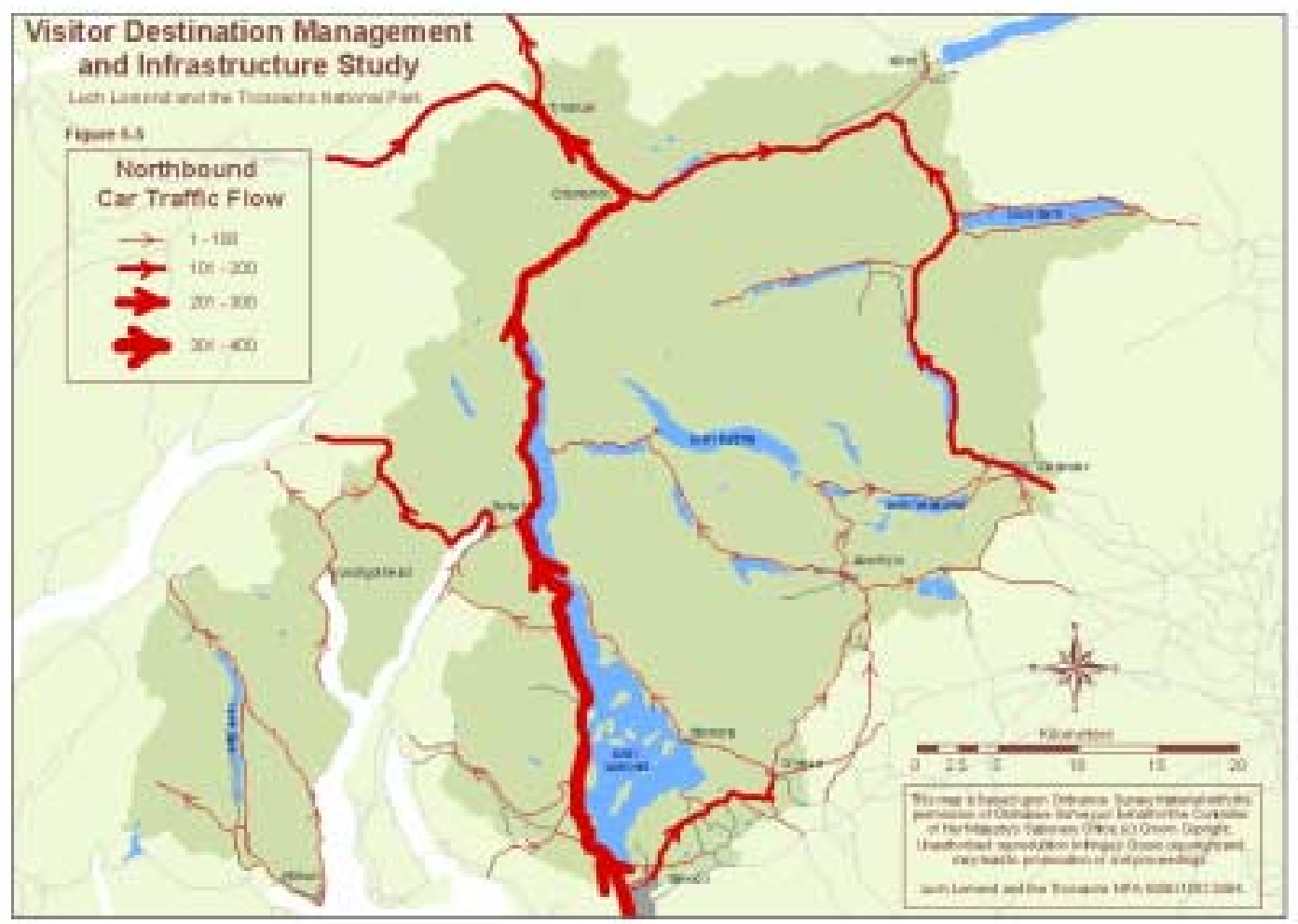

Source: (C) Loch Lomond and Trossachs National Park Authority (2004) 
Figure 6 Soutbound Flow

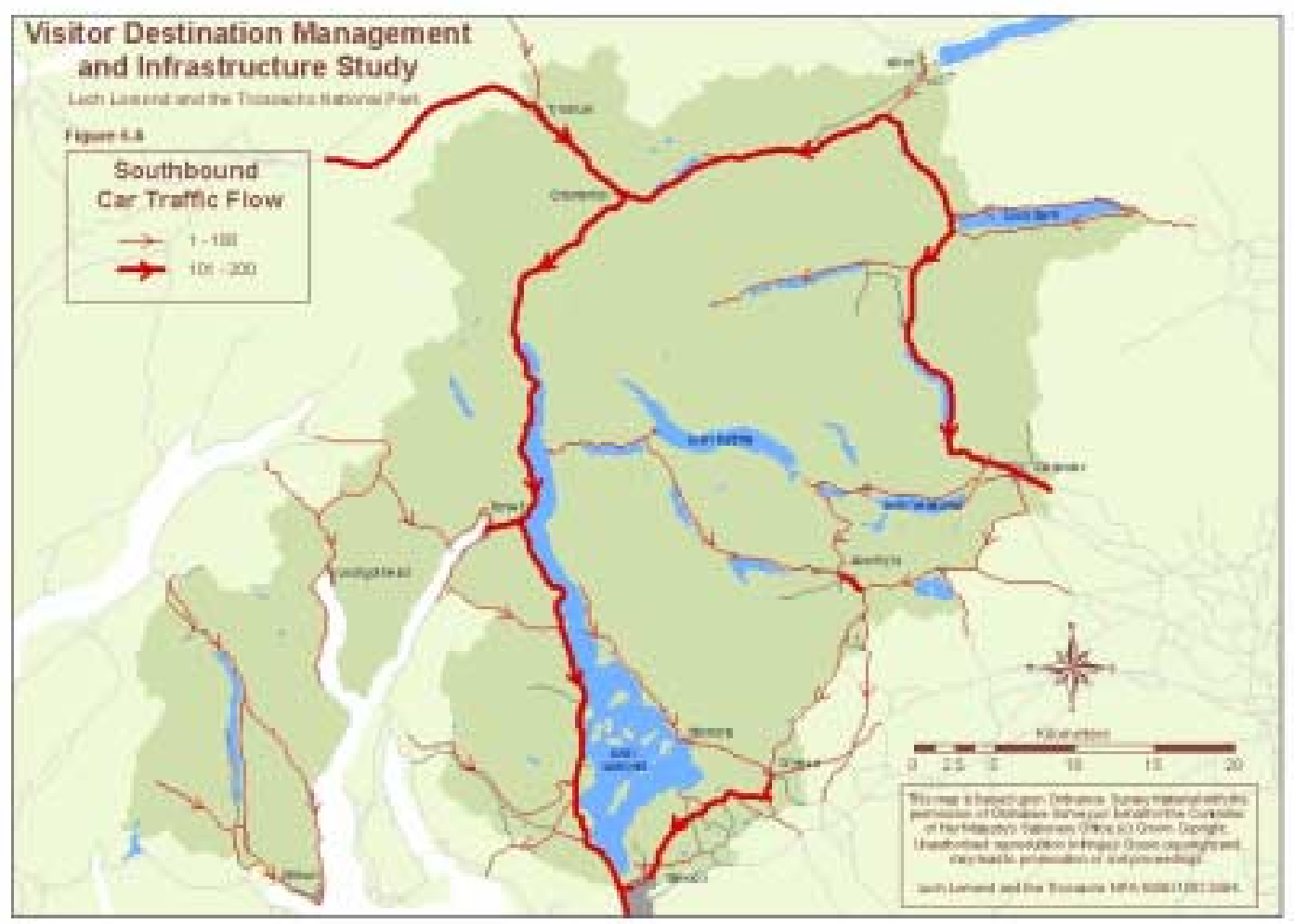

Source: (C) Loch Lomond and Trossachs National Park Authority (2004) 
Figure 7 Stopping Points

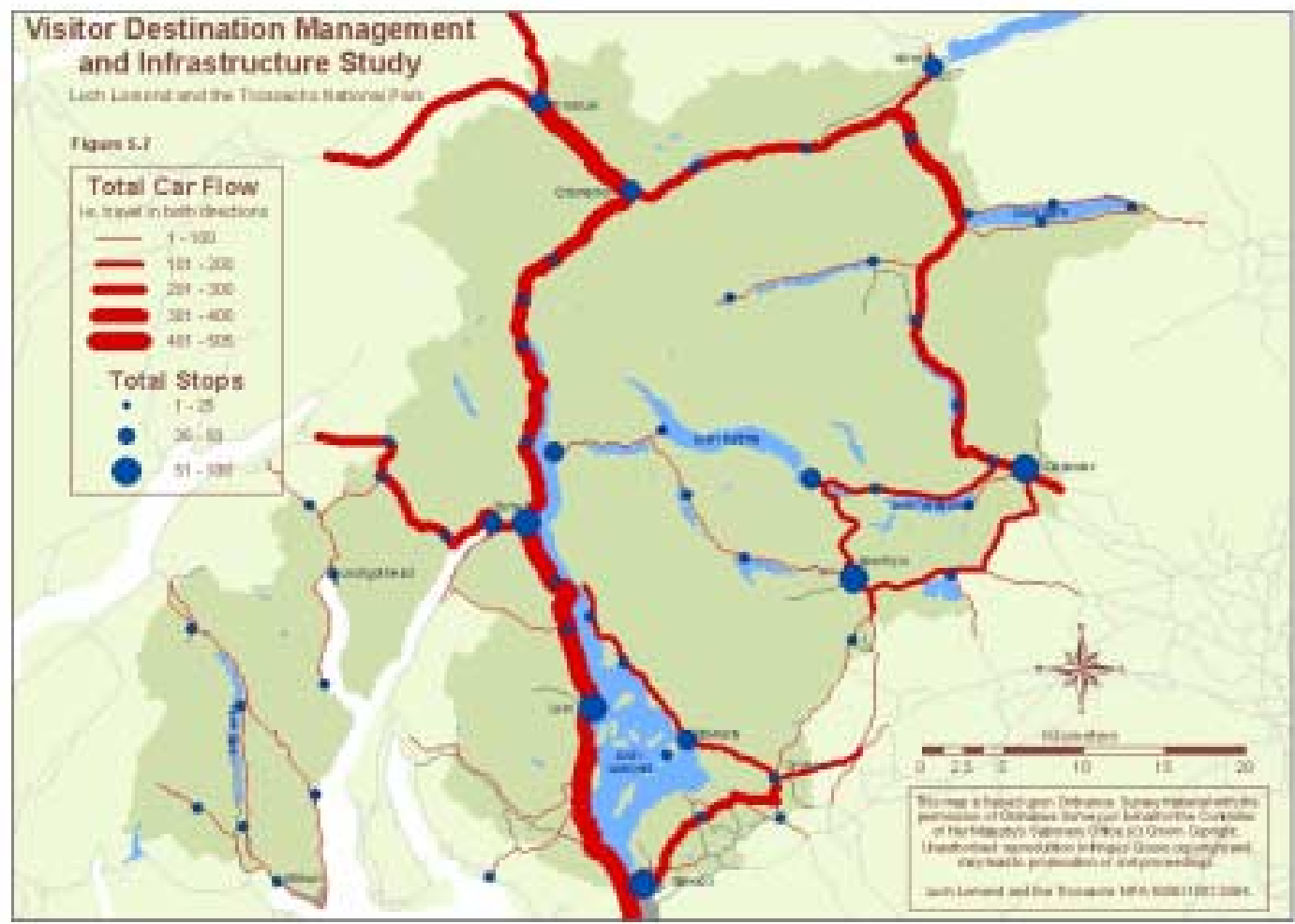

Source: (C) Loch Lomond and Trossachs National Park Authority (2004) 
Figure 8 Gateway Analys is:Balloch

ARROCHAR

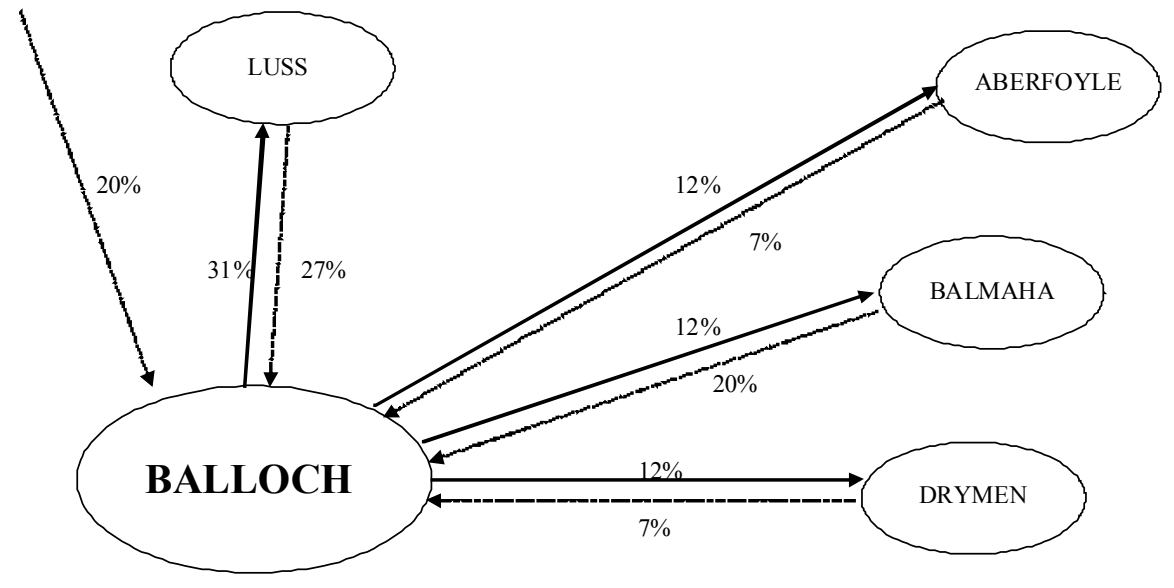

$\longrightarrow \quad=$ per cent of outward journeys from BALLOCH to next stop

$=$ per cent of inbound joumeys to BALLOCH from previous stop

Figure 9 Gateway Analys is: Calla nder

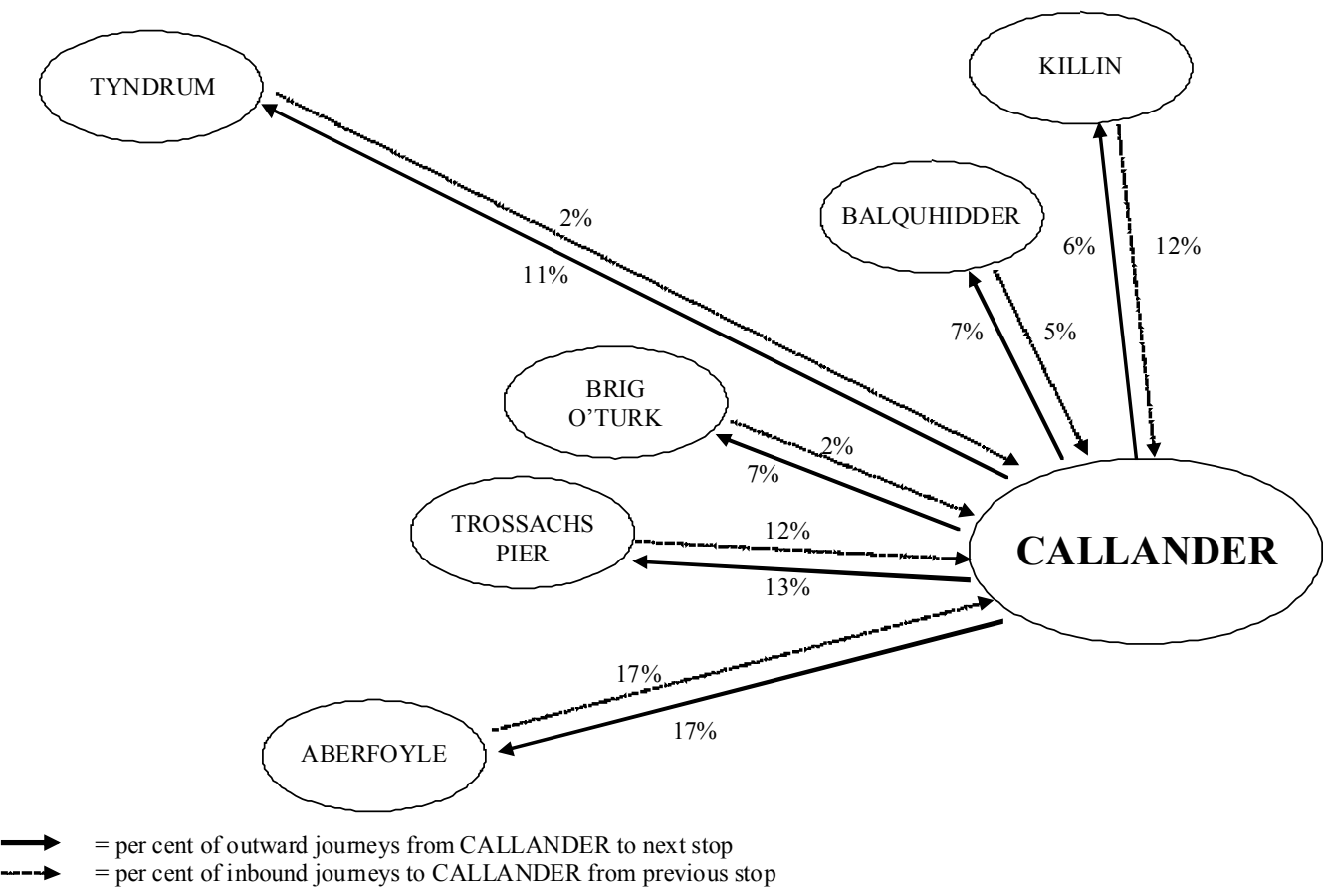




\title{
Exploring the spatial patterns of car-based tourist travel in Loch Lomond and Trossachs National Park, Scotland
}

\author{
Joanne Connell and Stephen J. Page ${ }^{* 1}$
}

\section{* Corresponding author}

\begin{abstract}
Car transport is a vital element in tourism yet there is a surprising neglect of the role of the car on tourism travel patterns, behaviour and activities. This exploratory paper focuses on the use of itinerary mapping as a useful methodology to identify how aggregate travel flow as well as more detailed individual itineraries can be mapped and understood using a Geographical Information System (GIS). The focus of this exploratory research is the Loch Lomond and the Trossachs National Park, Scotland first National Park established in 2002, where a variety of itinerary patterns are revealed through a map-based questionnaire of visitors using National Park roads $(\mathrm{n}=749)$. The implications for planning and policy initiatives are discussed.
\end{abstract}

\section{Keywords:}

GIS, Loch Lomond and Trossachs National Park, Scotland, Itinerary mapping, Car

\footnotetext{
${ }^{1}$ Joanne Connell, Department of Marketing, University of Stirling, Stirling, Scotland, FK9 4LA

* Stephen J. Page, Department of Marketing, University of Stirling, Stirling, Scotland, FK9 4LA

Email: s.j,page@stir.ac.uk
} 


\title{
Exploring the spatial patterns of car-based tourist travel in Loch Lomond and Trossachs
} National Park, Scotland

\begin{abstract}
Car transport is a vital element in tourism yet there is a surprising neglect of the role of the car on tourism travel patterns, behaviour and activities. This exploratory paper focuses on the use of itinerary mapping as a useful methodology to identify how aggregate travel flow as well as more detailed individual itineraries can be mapped and understood using a Geographical Information System (GIS). The focus of this exploratory research is the Loch Lomond and the Trossachs National Park, Scotland first National Park established in 2002, where a variety of itinerary patterns are revealed through a map-based questionnaire of visitors using National Park roads $(\mathrm{n}=749)$. The implications for planning and policy initiatives are discussed.
\end{abstract}

\section{Keywords:}

GIS, Loch Lomond and Trossachs National Park, Scotland, Itinerary mapping, Car 


\section{Exploring the spatial patterns of car-based tourist travel in Loch Lomond and Trossachs National Park, Scotland}

\section{Introduction}

Transport performs the vital element in tourism as an enabling element that facilitates travel, touring and tourism development, which is well documented in existing syntheses of the tourismtransport literature (Page 2005). Yet even within the tourism studies and transportation literature published across a wide spectrum of social science journals such as Transportation Research A-F, Transport Policy and the Journal of Transport Geography, there is a surprising neglect of the impact of the car on tourism travel patterns, behaviour and activities. Yet in domestic tourism, the car is now the most important mode of transport for tourists travelling to, and within, a destination. Research from human geography reviewed by Hall \& Page (2006) traces the interest in the car in recreation and tourism research, following seminal studies by Patmore (1971) and Wall (1971; 1972) based on research in the late 1960s. The basic premise in studies of the car in tourism and recreational patterns post-1945 is that the car has afforded greater flexibility to leisure users, but caused overuse at accessible (and seemingly inaccessible) sites. It remains the primary planning problem for sensitive natural environments such as National Parks, as well as in coastal and urban areas. This paper seeks to address the neglect in tourism research of the role of the car, by examining and highlighting the prior literature on this theme to re-establish its prominence as one of the critical problems relating to the sustainable use of many tourism and leisure resources. Use of the car is a dynamic and complex phenomenon in tourism, yet its powerful role in shaping tourism patterns and destinations has not really been explored in any detail by researchers. 
Consequently this paper explores a number of the complexities associated with the car as key element of human mobility by considering the car's use as a tool to tour, a fundamental concept in the operation and management of tourist activity. The concept of touring and itineraries, and their role in helping to explain tourist activity patterns, serves to illustrate how the impact of the car might be better understood and subsequently managed. Using (a) the example of Scotland's first National Park, the Loch Lomond and The Trossachs National Park (LLTNP), (b) the use of tourist itineraries as a research methodology, and (c) analysis using a Geographical Information System (GIS), the paper illustrates how the car influences tourist visitation. Such an approach overcomes the continuing research dilemma facing many National Park Authorities, which is that the dynamic nature and impact of the car is recognised, but the routine use of simplistic point-specific visitor surveys means that research is incapable of depicting the dynamics of multi-site visits as part of the wider visitor itinerary. But how have researchers viewed the car in terms of tourism research?

\section{The car and tourist travel: previous research studies}

Many studies by geographers since the 1930s in journals such as Geography have highlighted the recreational potential of the car (see Hall \& Page 2006 for a discussion), but the most influential study of car usage among recreationalists was Wall's (1972) study of Kingston-upon-Hull, using 1969 data. This built on previous National Studies, including the Pilot National Recreation Survey (British Travel Association \& University of Keele 1967, 1969), surveying 500 car users from Hull. Wall (1972) identified two enduring themes associated with the use of the car - seasonality and the timing of pleasure trips, and the growing dominance of the car amongst urban dwellers. This replicated many findings from the USA and other countries with the car as a form of recreation in its own right. For example, Coppock \& Duffield's (1975) survey of recreational activity in Scotland highlighted patterns of recreational travel, mapping the routes used by cars. This research and subsequent research by Coppock is widely attributed as the commencement of tourist 
itinerary mapping as a specialism and it did seek to explore visitation at a country level. One of the key findings of the study was the tendency of many car-users to not venture far from their car at the destination, admirably demonstrated in Glyptis' (1981) innovative study of recreationalists in Hull using participant observation. Many principles of logical positivist human geo graphy, using spatial methods of analysis such as gravity models, confirmed Wall's (1972) finding that car-trips by recreationalists tended to be concentrated at nearby leisure resources (e.g. the coast) and national parks (Wager 1967; Burton 1966), where the visual characteristics of the countryside and landscape were consumed by car-users. Similarly, Chubb (1989) reinforced these spatial principles and behavioural features of car-users, where the car was used in cross-border trips in the Great Lakes area of Canada/USA, using direct and circuit routes. Similar findings on longdistance car trips (e.g. Taplin \& Qiu 1997) modelled round trips made by recreationalists and the impact these travellers can have on small towns and locations. A recent study by Ryan and Gu (2007) has also confirmed that itineraries are an under-researched area of tourism research, noting the importance of ethnicity as a determinant of itineraries. Eby \& Molnar (2002) in relation to US scenic byways and Hardy's (2003) consideration of iconic routes confirm these principles. The economic development potential of such routes in rural areas is similarly highlighted in South Africa by Briedenham \& Wickens (2004). Conversely, the problems that the car can cause for tourist travel in relation to congestion and the impact on travel behaviour has been reviewed by Dickenson et al (2004) and Eaton \& Holding (1996), who emphasised the growing problems within National Parks.

In the public sector, research and policy advice associated with National Parks has consistently predicted the inability of such fragile environments to sustain growth in car traffic (e.g. Countryside Commission, 1992; Countryside Agency, 2003), with some agencies reviewing examples of best practice to address the planning and management issues associated with car use 
in National Parks (e.g. Transport for Leisure \& Smith 2001). This is critical in the UK where the Department for Transport, Local Government and Regions (2001) estimated that around 40\% of all car mileage is for leisure purposes, and the trend is towards travelling longer distances (compared to the findings of Wall (1972), which observed more localised car travel). These trips also tend to be more dispersed than commuting trips, posing additional problems in managing the impact of car trips. Page (2005) reviewed the initiatives devised in the UK to reduce leisure travel associated with the car including: travel closer to home; containment/restriction strategies; and improving alternative forms of transport including public transport or other modes such as cycling. However, these schemes have made only limited inroads into reducing the impact of the car due to inadequate marketing and publicity of alternatives, issues of ease of use of alternatives and a tendency to continuously cater for car parking. Dickenson et al (2004) pointed to the value of local leisure plans to help identify alternative uses, but for many rural areas (especially National Parks), the car remains the greatest threat to the sustainable use of the resource by causing:

- $\quad$ congestion at key sites (honey pots)

- $\quad$ pollution in small towns and villages where congestion routinely occurs

- $\quad$ visual and amenity pollution from unsightly car parking provision in areas of high scenic value

- $\quad$ loss of sensitive and rural land to provide car parking and associated infrastructure

- damage to existing environment through illegal parking on grass verges and in lay-bys which have minimal provision to accommodate peak usage

- unsustainable impact on communities unable to accommodate the sudden influx of car users in small scale environments, which cannot easily be managed, controlled or restricted. 
Despite these problems, which are well documented in the research literature on National Parks, there remains an insatiable demand from car users in many of these environments, where mobility forms a central component of the holiday experience or an element of a tour. For this reason, attention now turns to the concept of tours and itineraries.

\section{Touring and itineraries: key concepts for National Parks and Scenic Areas}

As McKercher \& Lew (2004: 36) poignantly argue, "little empirical or conceptual work has been conducted examining and modelling tourism itineraries, in spite of the long understood need to study this phenomenon". Whilst this commentary may still hold true, there has been significant research activity within New Zealand by researchers such as Forer \& Pearce (1984) and Forer \& Simmons (2002) in creating the knowledge base and methodological breakthroughs necessary using ArcInfo and national tourism data sets to map tourist flows. One consequence of this research is the creation of a research quantum and subsequent Visitor Flows Model for New Zealand (Becken et al 2007) to create a national model for itinerary mapping. Yet in each case, the research has yet to be used in a manner that can assist with infrastructure and capacity planning - a probable longer term use of such research by public sector agencies. What is also important to stress as a parallel development from the wider field of geography and GIS research is a range of developments in GIS-based research on human mobility and time-space dimensions of human mobility (Dahl, 2000; Suna \& Lydon, 2004; Zacharias, 2006; Huang, Yao and Raguraman, 2006) that has many common challenges in modelling tourist movements in time and space. However, much of this research has been more theoretical and methodological to develop frameworks which may be further developed for policy-making issues such as access to services, social inclusion and accessibility. 
While the lack of policy oriented research is partially explained by major practical problems in gathering data, (exemplified by the New Zealand experience, see Becken et al, 2007), where policy-makers engage in the process of such research they have recognised the implicit value of such studies to und erstand:

- the movement of people through space and time

- the impact of transport and tourism on infrastructure provision

- the effect of tourist movement to and within a destination, such as a National Park, and the services required

- $\quad$ the timing of tourist visits in terms of seasonality and peak use during a tourist's visit

- $\quad$ the need to prepare appropriate planning measures to manage/control/restrict or ban car use in National Parks

- the development of sustainable tourism strategies to balance the use of the resource base with the objectives of National Park plans.

From an academic perspective, McKercher \& Lew (2004) highlight a number of the principal conceptual studies that have shaped the development of geographical research on touring and tourist itineraries, many of which refer to early studies such as: Campbell (1966) and four modes of recreational travel, Coppock \& Duffield (1975) in Scotland, Forer \& Pearce (1984) in New Zealand who modelled coach itineraries and subsequent studies, with a new perspective provided by Becken (2005) using point pattern data from New Zealand's International Visitor Survey. Mings \& McHugh (1992) identified four types of touring route used by American tourists in Yellowstone National Park, while Lue et al (1993) examined multi-destination trips and Oppermann (1995) examined international travel, identifying seven possible itinerary types. Perhaps the best synthesis of these studies is Lew \& McKercher's (2002) review, which examined itineraries from a destination perspective (more detail on the wider range of studies can also be 
gleaned from Becken et al, 2007). This last paper reiterates many of the transport-related aspects of destination areas discussed by Page (1994) and highlights the fundamental basis of most discussion of itineraries - transport, the tourist and the process of touring, following a set or devised route (the itinerary).

From previous studies, McKercher \& Lew (2004) identified some 26 itinerary types and grouped these into the four categories illustrated in Figure 1 to aid the conceptualisation of tourist travel. Here, the itinerary can be seen in its simplest form as a single destination trip (out and back) following a route (with or without side trips). This is then expanded, in terms of increasing complexity to include a transit leg to the destination and a circle tour (the circuit) with an overnight stay at the destination. The next type is the circuit tour with/without egress points followed by a hub/spoke style of itinerary in which tourists are based at a destination from which return trips are taken to other destinations. In each model in Figure 1, two key elements exist: a transit component, and; a destination touring component. When one adds these components in to any model, as shown in Figure 2, one can begin to understand the complexity of modelling, classifying and explaining tourist itineraries.

Indeed, much of the research literature discussed by McKercher \& Lew (2004) explains tourist itinerary patterns as a function of: distance decay principles, market access (i.e. how accessible is the destination), the travel-time budget of tourists, income and cost, trip characteristics (i.e. the longer the trip duration the greater the ability to visit more places on a trip) and the differences between first-time and repeat visitors. Demographic variables and the socio-cultural differences of different groups also influence travel itineraries as Woo \& Page (2006) illustrate with the case of Korean coach tourists using highly structured and time compressed tours of New Zealand. Each of these factors has been extensively reviewed in both the transportation literature by economists, 
social psychologists and geographers to identify principles of tourist travel. Yet understanding of tourist flows remains a major gap in research, partly, as McKercher \& Lew (2004: 46) argue, explained by the "practical and operationalisation challenges" that this type of investigation raises. Whilst McKercher \& Lew (2004) suggest that the rise of GIS may help address this gap in research, improved knowledge is critical if interactions between the tourist and the destination are to be understood. Similarly, few studies have examined actual itineraries in a domestic context, with most focused on aggregate flows (Pearce, 1995). For this reason, the paper now focuses on the research problem - how to understand car-based tourist itineraries in the case of LLTNP to assess what policy is sues need to be addressed?

\section{Study a rea: Loch Lomond and Trossachs National Park (LLTNP)}

The LLTNP was formally established as Scotland's first National Park in 2002. The National Parks (Scotland) Act (2000) sets out the statu tory functions for National Parks in Scotland, most of which are similar to the purposes of National Parks globally (Butler \& Boyd, 2000). However, the major difference in Scotland is that promoting social and economic development is a core value, alongside the universally accepted aims of conservation and quiet enjoyment. Whilst it is widely acknowledged in National Park research that these environments will need to accommodate more vistors through time, Scotland's guiding strategy for tourism development to 2015 (Scottish Executive, 2006) seeks not to simply grow the volume of visitors, but to add value and increase spending and length of stay.

However, it is likely that the National Parks in Loch Lomond and Trossachs and Scotland's second National Park in the Cairngorms will have to plan for a continued growth in visitor volumes for two reasons: first, the landscape of these areas are key icons of Scottish tourism and are likely to remina key elements of the marketing proposition for VisitScotland; second, these environmenst 
are also becoming more popular as rural playgrounds for the expanding population base in Central and Northern Scotland aside from their tourist use. Where congestion poinst occur in the Park, especially at Gateways, the Park Authorities have sought to consider strategies to switch some use to public transport and other modes of travel, but these scehems are still at an early stage of development, including a feasibility study for a hydrogen bus in the Cairngorms funded by carbon offsetting from tourist travel. Scotland's National Parks therefore have to balance the contentious issues of economic development with conservation, which is far from an easy relationship to manage.

In summary, the aims of LLTNP are:

To conserve and enhance the natural and cultural heritage of the area, To promote sustainable use of natural resources of the a rea, To promote understanding and enjoyment (including enjoyment in the form of recreation) of the special qualities of the area by the public, To promote sustainable economic and social development of the area's communities.

While the statutory purpose of the National Park Authority is to ensure that these aims are collectively achieved in a co-ordinated way, if it appears there is a conflict between conservation and enhancement of the natural and cultural heritage and any of the other aims, then the Park Authority must give greater weight to conservation issues (Scottish Parliament, 2000).

LLTNP is located in west central Scotland, its southern edge some 25 kilometres from the centre of Glasgow. Some 15,000 people reside within the Park's boundaries in largely dispersed rural communities and a number of small towns. The major characteristics of the National Park are shown in Table 1, which also outlines some of the features of the area as a tourist destination. The National Park encompasses four distinct landscape areas: Loch Lomond, Scotland's largest inland body of water and an established recreation area for day visits from urban centres and tourists; 
Argyll Forest, a mainly forested area bounded by sea lochs; the mountainous country of Breadalbane, and the Trossachs, considered by many to be a microcosm of the Highlands with its mountains and lochs, epitomised in Sir Walter Scott's eighteenth century literary works that stimulated tourism in the area (Gold and Gold, 1995). In terms of car use, while $68 \%$ of tourism trips in Scotland are made by car (VisitScotland, 2006), in the National Park area, a relatively remote rural area, car use is much higher at around $85 \%$ of visits (LLTNPA, 2005). As a tourist destination, LLTNP is problematic for transport flow research because several major arterial routes pass through the region. The spatial configuration of these routes substantially reduce the feasibility of undertaking a cordon survey of visitors, since there are too many routes into and out of the area, and it is a region passed through with limited stopping times and points for non-Park oriented visitors travelling to/from the Highlands and Islands of Scotland. Against this background, and with limited data, knowledge and a stated need for the National Park Authority to develop a spatially informed National Park Plan to understand the dynamics of visitor behaviour in time and space, several research problems were formulated. These included: what is the current nature of visitor behaviour, how is it impacting upon the Park in terms of where visitors spatially concentrate and disperse to and what management requirements might be required at specific sites in view of the scale of visitor use? These issues may seem somewhat straightforward in academic research terms, but from a practical perspective, no prior data sources existed for the entire National Park area, being a new creation and cutting across a multitude of public sector agencies (e.g. four regional development agencies and four local authorities) who collated data in different ways and where no data existed on certain aspects of visitor activity. Therefore, this study sought to establish a baseline of data to scope and outline the spatial characteristics of visitation to the National Park to develop a holistic assessment of visitor activity and inherent planning needs. In essence, the research aimed to inform the development of discrete planning zones for visitor activity as part of a much wider study, the scope of which is too extensive to report in this paper. 


\section{The Research Problem - Why use GIS?}

GIS has been widely used in both the public and private sectors where organisations wish to appreciate the geographical characteristics of recreation and tourism (Hall \& Page, 2006). Yet relatively few studies exist in relation to the use of GIS in tourism research with some notable exceptions (see Becken et al, 2007 for studies since the late 1990s). Examples include work on tourism planning in Scotland (Duffield and Coppock, 1975), sustainable tourism (Bahaire \& Elliot, 1999), recreational resource management (Klinsky, 2000), and tourism marketing (Elliott-White \& Finn, 1998). Boyd \& Butler (1996) used GIS to identify suitable areas for ecotourism in Northern Ontario, highlighting that the ability to incorporate the dynamics of tourism and recreational activity and their impact on tourism and recreational resources has a major role to play in tourism

planning. However, GIS remains a largely untapped area where major synergies exist between the academic pursuit of tourism research and developments in human movement research). This approach harnesses the skills of the geographer in creating a complex tool for data capture, analysis and interpretation in defined regions and areas that have very precise and identifiable boundaries, such as National Parks.

Advances in computer technology, such as ArcInfo, have meant that more sophisticated systems now exist in research terms to search, query, present and analyse data in a spatial context. A major strength of GIS is the complex data entry and storage facility it offers to analyse multiple dimensions of a location in terms of data manipulation, map production, database integration, data querying, search analysis and modelling of data, thereby enabling researchers to assist decisionmakers in planning decisions. Therefore, GIS was selected in this study in view of its power and potential to in tegrate a range of data sources to produce an assessment of spatial activity of tourists in LLNTP in relation to the research questions posed. In this paper, the focus is placed on car- 
based data capture as a means of understanding the dynamics of visitor activity as is now discussed below.

\subsection{Rationale for car traffic data capture: itinerary mapping as a research method}

Studies of car borne visits to National Parks in England and Wales in the 1960s and 1970s indicated that visits were not itinerary or route-led, but often formed convenient stops on 'A' class or major roads. Such use patterns suggested that National Parks were not considered as destinations but as a series of places to visit. In this respect, behaviour can sometimes be spontaneous, especially in the case of transit tourists simply seeking a comfort break. Alternatively, the journey to a destination is not just utility, but an important focus of the recreation experience (Clawson \& Knetsch, 1966). Visitors do not always take the most rational or shortest route to a destination but often follow a scenic or quieter route, seeking not to minimise journey time but to include the journey as part of the recreation experience. Indeed, early car touring guides of the Trossachs illustrate this very point, a long time before National Park designation. Thus, while it is relatively easy to collect data on visitor profiles, for management purposes it is of paramount importance to unders tand the dynamic element of visitor activity and behaviour. Such issues illustrate the importance of itineraries and elevate the need to understand how and why visitors travel around and through an area. Such variables are complex, increasingly diverse and more flexible due to the ease of travel afforded by the car when compared with the itineraries of the nineteenth-century provided by Thomas Cook (Cook, 1861) based on rail/coach tours to a set number of attractions on a specified itinerary in the Trossachs.

Itinerary mapping is a useful but little used technique in visitor research. It is particularly us eful for identifying which vehicular routes are used in specific geographic areas, as well as analysing tourist flows, activity patterns and the visitor dynamic asso ciated with each route. The process 
allows route patterns and stopping points to be determined, the likely impact of tourist use and subsequent management implications. The relationship between visitors and destination areas in the Park can be much more clearly understood, especially where multiple site visits on one trip are undertaken. This method complements the more traditional format of visitor survey work, which does not allow for an adequate understanding of the dynamic and spatial elements of visits. Nor do such surveys single out visitors who do not stop in the Park, but whose activities need to be known from a route usage and planning aspect. Collecting itinerary data also allows the identification of heavily used tourist routes, information that helps to better understand data from Automatic Traffic Counters ${ }^{1}$.

\section{Tourist car itinerary mapping: methodology}

A self-completion map-based questionnaire was designed to capture data about a visitor's most recent trip to or through LLTNP, and aimed to identify and evaluate: visitor flows for the period March to October 2003; National Park entry and exit points; routes followed and directions; stopping points and reasons for stopping, and $\mathrm{v}$ is it patterns.

As a cordon survey was prohibitive bearing in mind safety, practicality, cost and geographic parameters, the next most effective method of capturing such data was by means of a postal survey. In conjunction with the Argyll, the Isles, Loch Lomond, Stirling and the Trossachs Area Network of VisitScotland, Scotland's National Tourism Organisation, a sample of 5,000 people was taken from a domestic visitor database. This large sample was selected in order to gen erate at least 500 responses, as a $10 \%$ response rate to postal surveys is often to be expected, particularly when a graphical element is included in the survey instrument. Some $50 \%$ of addresses included

\footnotetext{
${ }^{1}$ Whilst the research collated the Automatic Traffic Counter data for the National Park, poor maintenance of these counters over time meant only partialdata was available and not suffic ient in terms of quality and timescale to adequately provide a detailed baseline of data on traffic flows in the National Park area and the contribution of tourism traffic to overall traffic flows. One cons equence of this res earch has been the introduction and more regular maintenance of these counters.
} 
Scottish postcodes and 50\% were from the rest of UK, which broadly mirrors the tourist population to the area. Postcodes local to the Park and likely to constitute utility trips were excluded. As such, the survey aimed to measure tourist flows rather than community trip activity. While it is recognised that international visitors form a small generator of visitors to the National Park, a different methodology would be required to capture data that would be both valid and reliable. Such a survey was beyond the remit of this particular study. Therefore, one potential bias in the study relates to the absence of in ternational visitors (compared to the New Zealand Flow model described by Becken et al, 2007). A further bias may relate to the method of data capture, because the map-based survey did not seek to collect more detailed Scotland wide itineraries within which a more complex series of hierarchical trip patterns might be constructed. Yet despite these weakn esses, it should be remembered that $86 \%$ of tourism trips to Scotland are domestic (VisitScotland, 2006). The vast majority of these are car-based. Hence there was a justification for exploring the activities of this specific market to inform the then current National Park planning process (at that time in its early stages) rather than seeking to develop a more complex model (e.g. as proposed by Becken et al (2007) which would not have been with in the Park's time horizons. In this respect, a judgement needs to be struck between application, methodology and the ability to report findings in a timely manner. It should also be stressed that this study was deemed to be exploratory, developing an understanding of itinerary mapping at the micro level, while also contributing to preparatory National Park planning by enabling spatially-contingent data to be captured that depicted some of the then current patterns of tourist activity in the Park. Therefore, the study must be understood as a micro-scale example of the capability of what GIS and tourism research may feasibly do when applied to a local research problem, and only in that sense might it be said to inform a wider literature. As such the research is only the first stage in developing a framework for further inv estigations on regional tourist travel patterns. It does not seek to achieve 
the sophistication of large government funded research programmes as illustrated by the New Zealand Flow model.

A total of 749 usable questionnaires were returned, yielding a response rate of $15 \%$. Response rate by postcode area indicated a good geographic spread of responses with approximately $46 \%$ of responses coming from Scotland and 54\% from England and Wales. A total of 1013 stops were recorded by respondents. Initial descriptive data analysis was undertaken to identify basic characteristics and more qualified responses given by respondents. Detailed statistical analysis of these data was not an objective of this research, as a more broad exploration of the traffic flows and individual itinerary patterns was more appropriate to establish a basic understanding of car use in the Park area. The data were digitised and tran slated in to GIS, allowing a detailed spatial evaluation of vehicular flows. While a descriptive analysis of itineraries through questionnaire surveys provides useful information for policy and planning perspectives, the use of GIS mapping and data manipulation allows an appreciation of the flows and intensities of vehicular use, building into a spatially informed understanding of the dynamics of tourist movement in the National Park. The process of analysing itineraries through GIS is now discussed, leading to an evaluation of the implications of (i) the research findings and (ii) the use of GIS in tourism research.

\section{Analysing it in eraries: digitisation and mapping}

Data analysis took two main forms. First, a basic analysis of the questionnaire was undertaken to derive useful baseline information gained from respondents. Second, the map part of each questionnaire was digitised to map travel itineraries. For this, it was necessary to create a digital road network. OS Strategi (derived from 1:250,000 scale mapping) was used as the base network for th is exercise. All roads both within or intersecting with the National Park boundary were selected. A topologically consistent network was derived whereby lines were split at, and only at, 
road junctions. Each road section was given a unique identifier as shown in Figure 3 and every road element had a direction component (deriving from the direction of data capture and visualised using an arrow symbol set). Individual arcs were 'flipped' to produce a South to North networkand this then reversed to produce a North to South network as shown on Figure 4. In order to capture each car route, the relevant roads were selected as appropriate from either the roads-south or roads-north network. Subsequently, roads-south and roads-north were merged and to create a 'shapefile' that depicted the flow of traffic in both directions along National Park roads. Once all the individual routes were collected, these were then 'merged' into a 'master flow' file. The flow of traffic in both directions along each road section could then be established. The results of both analyses, combined where appropriate, are now discussed.

\subsection{Journey characteristics}

Descriptive analys is of the questionnaire part of the survey yielded some interesting basic findings. Nearly two-thirds of respondents were on day trips to the Park or elsewhere, while $35 \%$ were staying overnight in the Park illustrating the strong day trip catchments of the Park in central Scotland, given its proximity to Glasgow and historical associations with Loch Lomond as a day trip destination from the late nineteenth-century (Durie, 2003) resulting from regular rail links and Clyde paddle steamers that provided access to Western areas. In particular, the Loch Lomond and Trossachs areas are long-established touring destinations, as identifiable from historic touring guides. Thomas Cook devised 14-day tours from England to Scotland, including a 3-day circuit tour by rail and coach from Stirling, with several stops in what is now the National Park. Similarly, an excerpt from the Queen's Newspaper Book of Travel (1910) promotes a 2-night to ur of the area of a type clearly identifiable from survey itineraries nearly 100 years later (Page, 2003). In contemporary times, the National Park area, and particularly the A82 corridor, receives a high proportion of traffic passing en route to another destination, particularly Oban and Mull, Glencoe, 
Fort William, and further into the Highlands, as well as the A83 route to destinations within the Argyll and Bute region, illus trated by $51 \%$ of itineraries in this study. Such patterns are seen in other regions that act as transit regions (e.g. the South Kent and Calais area in the Transmanche Euroregion), where those engaged in tourism and visitor management have to grapple with creating and managing a perceived destination zone, where visitors will stop, stay and spend. However, LLTNP is not simply an en route destination, acting also as a single destination, a touring circuit and a hub and spoke style of visit, as this paper will later discuss and which confirm the existence of McKercher \& Lew's (2004) itinerary types. This in itself makes a complex task of understanding multi-layered and multi-faceted itineraries and Park use. Before discussing these implications, the findings from further analysis through GIS mapping are explored.

\subsection{Total tourist traffic flow}

Figure 4 illustrates the total flow of car traffic in the National Park, which clearly establish es the dominance of the A82, the major north-south route connecting central Scotland with the Highlands ${ }^{2}$. The A 82 is heavily used where A85 traffic joins the route. The A82 is more heavily used between Balloch and Tarbet, where a moderate amount of traffic diverts from the A 82 to the A83 route to Argyll. The A84, which links eastern central Scotland with the Highlands attracts moderate use. What particularly stands out is relatively heavy use of a minor no through road on the east side of Loch Lomond, which runs through a quiet area with no major built attractions, but offers good access to the loch, surrounding hills and informal recreation sites. Routes attracting less use include those to and from St Fillans (east) and Dunoon (south west). Figure 4 shows the importance of the A821, known as the 'Trossachs Trail', a public sector funded initiative aimed at encouraging tour ist exploration of the Trossachs, which pre-dates the inception of the National Park (see Caffyn, 2003, for a review of development of tourism in the Trossachs). This route is

\footnotetext{
${ }^{2}$ Transport Scotland, www.transportscotland.gov.uk
} 
particularly scenic and offers easy access to the Trossachs and is very much an historical recreation of Victorian interest in the area as embodied in guide books of the time (e.g. Blacks, 1894). To understand vehicle flow with more accuracy, the Northbound and Southbound flows are now examined.

\subsection{Northbound traffic flows}

Figure 5 illu strates the northbound flow of car traffic in the National Park, and demonstrates heavy use of the A82 northbound, with a substantial amount of traffic travelling out of the National Park at Tyndrum en route to Glencoe, Fort William and Skye (A82), Oban, Mull and the Isles (A85). Proportionately less traffic but a still moderate flow was recorded on the A83 and A84, while low levels of northbound traffic were recorded through the Argyll Forest. Some itineraries with Oban as the destination took the A83 alternative route rather than drive along the narrow stretch of the A82 from Tarbet to Crian larich. It is well-established that many independent self-drive holidays in Scotland adopt a clockwise tour of the Highlands, from Glasgow to Loch Lomond, north to the west coast and is lands, across to the east side, south through Perthshire and finally to Edinburgh. A number of tour itin eraries available on the world wide web (WWW) promote this geographic exploration of the country. It is not entirely clear why this is the case, although historical touring antecedents seem to confirm the existence of a clockwise preference. One possible explanation is that on the west side of Scotland, from Glas gow northwards, majestic mountain scenery, much sought by visitors, is encountered within a relatively short distance compared with the softer landscapes of the east.

\subsection{Southbound traffic flows}

Figure 6 illustrates the southbound flow of car traffic in the National Park. Corresponding to the analysis resting on the clockwise tour of Scotland, the south bound itinerary maps indicate a much 
lower proportion of traffic travels south than north. While southbound A82 and A83 traffic into the Park is substantially lower than northbound, southbound A84 and A85 traffic is similar to northbound patterns, and similar north and southbound patterns on other routes are also noted such as the A815 and A81 into and out of Aberfoyle. These patterns might be more indicative of hub and spoke and circle tour itineraries. More traffic enters the Park at Balloch than exits. More trips out of the Park at Killin were recorded compared with journeys into the Park. Overall, a strong east to west, and south to north pattern of traffic movement is identified which confirms the anecdotal acceptance of clockwise tours northbound on the A82 and southbound on the A9. Further confirmation of this is provided through respondents' comments on the questionnaires.

\subsection{Car stopping points}

Figure 7 identifies the car stopping points, the plethora of places at which visitors choose to stop and the locations with the greatest number of recorded stops (Luss, Balloch, Callander, Aberfoyle and Tarbet). It also illustrates the pattern of stops made in other areas, including those at more remote locations. This raises a fundamental question relating to the route patterns emerging from the study that may begin to shed light on the nature of tourist itineraries in the LLTNP. While it has already been established that many visitors do not stop at all in the Park, of those visitors who did stop, $46 \%$ stopped once, while $42 \%$ of respondents stopped twice or more. The mean average number of stops (excluding no stops) was 2.09 per itinerary, while the median and modal average was 1.0. Including all respondents (i.e. those who did not stop en route and those who did), the mean average falls to 1.83 stops.

\subsection{Reasons for Stopping}

Excluding overnight stays, the reasons given for stops were diverse, ranging from the more conventional National Park activities of hill-walking and sight-seeing, to more personal and 
obscure reasons, such as genealogical visits to a cemetery, through to more utilitarian reasons, such as dog walking and requiring toilet facilities. The most popular reason for stopping was to partake in refreshments (with purchasing food/drink five times more likely than picnicking, see Table 2). Such a finding reflects much of the conventional wisdom on the geographical siting of hospitality establishments on accessible route ways. Refreshment stops accounted for the largest number of stops made by those just passing through the Park (57.3\% of those passing through and making a stop did so for refreshments), followed by taking a short walk. For all other categories of reasons for stopping; those visiting the Park accounted for a greater proportion of visitors engaged in each activity, compared with those who were just passing through (Table 3). The major reasons for stopping reflect the more general use of UK National Parks, e.g. for quiet enjoyment, relaxation and outdoor pursuits (Countryside Commission 1994), as well as one of the objectives of creating the LLTNP.

\subsection{Stopping locations}

By examining the stopping points, one can begin to understand the basic nature and shape of the itineraries that tourists followed. Overall, a large number of visits were made to a small number of sites, and vice versa. Five of the most visited locations were settlements around the shores of Loch Lomond, highlighting the focal area of the Park in terms of visitor usage, while other major gateway settlements and honey pot sites accounted for the remainder. Yet this in itself does not explain why people chose to stop at specific locations.

To understand some of the behaviour in relation to visited LLTNP locations, reasons for stops in specific locations were calculated for those places where the highest visitor numbers were recorded (Table 4). While it is possible to calculate such statistics for all sites, small numbers of visitor at some locations would produce unreliable results, thereby limiting analysis to those sites with 
significant guest numbers. As already established, the most important reason for stopping in all locations is for refreshments/picnics but this is particularly high in Luss and Callander. The number of people stopping for retail purposes is gen erally not high in LLTNP, but is highest at Balloch where a purpose built retail attraction with a Visitor Gateway Centre was developed as an anchor attraction for the new National Park. More people stopped at Balloch for a utility/comfort break than at other locations, and it is a 'natural' stopping point on journeys through and into the Park. Balmaha forms a particularly important location for sightseeing because of its scenic qualities and access to Loch Lomond and the West Highland Way, a long distance foot path.

This analysis identifies several issues about the use of the Park's honey pot locations. For example, Luss is a heavily visited small village, which cannot accommodate large numbers of cars or people. The research identifies that a large number of visitors make stops at Luss for various purposes, but most $\mathrm{v}$ is its are relatively short in duration, indicating a heavy impact on the locality through the use of the car. Conversely, a more appropriate stopping place for en route travellers is the purpose-built site at Balloch, with ample parking, services and space for visitors. Itinerary mapping in this case helps to confirm anecdotal experiences and observations, providing some evidence for planners attempting to shape visitor behaviour. More detailed analyses of individual itineraries can add an extra dimension to such evaluations.

\section{Itinerary types and route analys is of to urist trip patterns}

By exploring each individual itinerary, some gen eralisations can be made about the nature of car travel in the LLTNP. The ensuing discussion considers the whole itinerary of each respondent, the patterns of leisure stops within the National Park and the use of gateway and egress points.

\subsection{Itinerary types}


Based on McKercher and Lew's (2004) simplified typology of itineraries, the travel patterns identified in this study reveal somewhat distinctive spatial variations in the way in which visitors experience the National Park. It should be emphasised that conventional itinerary analysis usually looks at the derivation of the route pattern from, and return ing to, home. In this study the limitations were that the only captured itineraries captured were those of the trip through the National Park. Furthermore, the identification of the itinerary types were not easily categor ised following McKercher and Lew's schema, although reference to the studies that McKercher \& Lew built on does aid explanation of some features of the itineraries developed in this study. For example, there were no precise circle tours, as these would indicate a circuit starting and finishing from home. As most visitors were on holiday, the type of circle tours seen were those involving a transit leg and then a circle tour.

The distinguish ing feature of itineraries in the National Park area is that some $63.3 \%$ of journeys are 'en route' to another destination. However, the phrase 'en route' hides a range of different journey types as some $25.6 \%$ of journeys pass straight through the Park area without stopping, while a further $37.7 \%$ are en route elsewhere but stop one or more times during the transit stage through the Park. This form of itinerary most reflects Lue, Crompton \& Fesenmaier's (1993) 'en route' itinerary, and, while different, contains some similarities with Opperman's (1995) 'stopover' categorisation. To some extent, the National Park might also signify use as a 'touring destination', as defined by Lew \& McKercher (2002), being a half-way stop between the major cities of lowland Scotland and the Scottish Highlands (i.e. between stopover points on an itinerary). In terms of McKercher \& Lew's (2004) framework (Figure 1), the dominant itinerary is the 'single destination with or without side trips', with the National Park being a side trip and the single destination being outside the Park. 
If one examin es more purposive visits to the National Park for day and overnight visits, where an en route destination is not the main purpose of the visit, then some $36.7 \%$ of all itineraries were identified. Just over one-half of these itineraries are best defined as 'single destination' (McKercher \& Lew 2004), where journeys are made to a single place within the Park, with or without side trips, and including or excluding one or more nights' stay. A much smaller number (11.3\% of the total itineraries) comprised a transit leg and circle tour in the National Park (some of which did go outside the Park boundaries to return in again at a later stage on the same leg of the journey). Such findings might be surprising since the Mings \& McHugh's (1992) study of Yellowstone National Park found that more than half of the respondents took a 'full orbit' or circular tour. In areas of designated scenic beauty, particularly promoted for visitor enjoyment, one might expect such a pattern to dominate. The final itinerary type is broadly defined as 'hub and spoke' (McKercher \& Lew 2004) or base camp (Lue, Crompton \& Fesenmaier, 1993; Opperman, 1995), which formed the least significant style of itinerary among respondents - a mere 5.4\% of itineraries. Hub and spoke itineraries were confined to those respondents who were staying several nights at one location within the Park and taking day trips out from that accommodation base. This finding is not entirely surpris ing given that numbers of visitors staying in the National Park is low compared with the surrounding region of Argyll and the Isles, while the number of day visits and transient visitors en route is known to be much greater (Loch Lomond \& the Trossachs National Park Authority, 2005a). These findings alone pose a number of debates, difficulties and challenges for planners and policymakers engaged in the process of developing and implementing proposals and initiatives for sustainable tourism in a Park-wide context. Some exploration of patterns of stopping points is now appropriate to illustrate some of the key concepts that dominate patterns of travel. 


\subsection{Interpretation of Tourist Travel Patterns: Stopping Behaviour}

Locations where the greatest number of one stops were made included Luss ( $13.1 \%$ of all one stops), followed by Balloch (9.3\%), Callander (8\%) and Arrochar (7.7\%). To some extent, these statistics reflect the total number of $v$ is its to each location, but calculating the number of itineraries where only one stop was made by the total number of stops at a given location ind icates the proportion of visitors to a location that are just making one stop in the Park. Such findings are of greater value in a policy context, helping to illuminate types of demand and usage patterns in specific locations.

It is evident many of the locations where a large proportion of visitors are 'one stoppers' are on the main trunk routes, and therefore provide an opportunity for en route travellers to break their journey. Other locations provide specific interest for visitors, who will travel to that place only, without exploring the immed iate vicinity. Locations that attract a greater proportion of visitors that are making more than one stop are more likely to be off the beaten track (i.e. further away from arterial routes) and part of a touring itinerary within the Park.

Spatial patterns of two to five and more than five stops were analysed. Only 22 itineraries were identified with more than five stops, so only an indication of reasons for multiple stops can be suggested. More than 8 stops were even more unusual in the dataset. However, one respond ent stopped a total of 17 times during the course of a four-night stay, following a clockwise circuit around the Park from Dunoon to Balloch reminiscent of the Victorian circuit tour (Blacks, 1894). Reasons for stopping included painting and photography, as well as walking, cycling and camping. It should be noted that multiple stops do not necessarily indicate the presence of overnight visits. A number of people toured the Park en rou te to another destination, some of who stayed overnight in 
the Park, while others were en route day visits. Other multiple stopping routes involved the A82 for visitors using this road as a through route, but making stops for refreshments, walks and photos.

While the numbers of respondents recording multiple stops were relatively low, the data indicate (a) the entry point into the Park for these types of trips is Callander, and (b) tended to be routes taking in either the Trossachs Trail and/or a trip northwards along the A84 to Killin. These results indicate the importance of distinct areas of interest for visitors keen to explore the Park. In this case, the areas included: the Strathyre/Balquhidder/Lochearnead/Killin area, the Trossachs Trail route and the settlements and recreation sites en route, especially Loch Katrine/Trosachs Pier and Aberfoyle. These findin gs highlight the potential significance of gateway points.

\subsection{The importance of gateways and egress points}

Gunn and Var (2002) express the significance of gateway settlements in the planning, development and management of tourist destinations. A gateway acts not just as an entry point to a destination and a location from where visitors can source information, but a place that works with the visitor experience to form an impression of the whole destination. As such, the role of a gateway is particularly crucial in a number of respects, including the timely provision of $\mathrm{v}$ is itor information, interpretation and education, shaping visitor behaviour, and influencing visitor stay and onward travel patterns. Similarly, egress points, as the last place visited before return home, help provide the visitor with a 'sense of closure' or last experience of place before preparing to return home (Lew \& McKercher, 2002). In most cases, gateway and egress points are the same locations in LLTNP, while the geography of LLTNP means that there are several such locations in the Park.

The research findings illustrate that in terms of numbers of trips both Balloch and Callander are the 
most important gateways to the LLTNP, with about the same number of first stops in the Park recorded (see Figures 8 and 9 for a schematic representation of these travel patterns).

The data suggest a hierarchy of gateway communities, where the largest number of people currently enters the Park and where the greatest infrastructure demands will be placed. In order of high to low to tal volume of traffic, the hierarchy places the key locations in the following four-fold order of significance:

Class 1: these are the primary gateways and experience the highest volume of traffic into and out of the National Park on trunk roads. Class 1 gateways tend to act as egress points and offer a range of tourist services. The two primary gateways are Balloch and Callander.

Class 2: these are secondary gateways, which experience high volume of traffic into and out of the National Park on trunk roads, but less than Class 1 gateways. Where there is a settlement, it is likely to be an egress point and offer a small number of tourist services. The two secondary gateways are Tyndrum and Butterbridge.

Class 3: these are gateways on more minor routes, carrying more moderate volumes of traffic in and out of the National Park mainly through minor rural settlements, such as the small villages of Aberfoyle, Drymen, Kill in and St. Fillans.

Class 4: these are minor gateways, with the smallest volume of traffic in and out of the National Park through quieter locations, such as Port of Menteith and Dunoon/Benmore. These gateways are the least likely to be used by en route tourists.

This classification provides a spatially-contingent framework for deploying resources to manage car flows and potential sites for further investment to better accommodate car-related tourism. Yet these results also have a wider significance when examining the link with tourism planning per se. 


\section{Implications: using itinerary mapping to inform touris $m$ planning}

The research has identified the value of this spatially-focused approach to car-based travel within the LLTNP as a basis to develop appropriate policies that reflect user needs and offers a potential contribution to the sustainable development agenda that seeks to plan and manage sites appearing to attract different forms of $v$ isitor behaviour and pressures. One good example is sites that draw a large number of visitors who are stopping only once in the Park. While it is essential to know the reasons why stops are made in terms of infrastructure requirements (for instance there is a large difference between a hill-walker and a person stopping for a cup of tea), planning implications for extending visits or increasing awaren ess of tourism opportunities are inherent, particularly giv en the context for developing sustainable tourism and promoting alternative forms of transport in this area. Current research underway in 2007 on future transport needs for Scotland's National Parks reiterates the problems which car-based tourism poses and the major challenge in seeking to shift visitors at key sites to public transport alternatives as part of a sustainable development agenda to reduce overcrowding. Other aspects that the survey has raised include the relative importance of gateway communities, the use of the road system in the park including minor roads, and the degree of passing through car-based traffic. The study has also been used to inform the LLTNP Park Plan (LLTNPA, 2005b) by establishing the geographical bas is of visitor destinations and the nature of car-based tourism in the Park area, in which is the dominant mode of travel. Fundamental understandings of the way in which visitors travel in and around the LLTNP are a prerequisite to establishing a planning framework to manage visitor behaviour and allocate resources to tho se areas of greatest need in terms of managing the conservation and enjoyment of the LLTNP area.

The research has also shown that even when policy-makers draw a line around an area and designate it as a National Park, it is not necessarily the case that the data and tools readily exist to understand what this means for the creation of a tourism and recreational resource that can meet 
the needs of the Park Authority, visitors and the local community. While the full findings of this research are too extensive to report in this paper, the research has highlighted how itinerary types can be applied in the context of LLTNP, and the management implications for policymakers are now discussed.

\subsection{The desirability of itinerary types}

The implications of identifying itinerary types within a specified geographic area have significant potential in informing policy developments in a spatial context, rather than in a more linear, initiative-driven style that best describes much sustainable tourism planning. Clearly, LLTNP is not yet viewed and used primarily as a single destination. Despite the National Park often being used as a transit area in a tour of Scotland is not necessarily a negative feature, en route itineraries create little or no economic benefit and simply add to the environmental costs of car-based tourism. Is this an issue for the National Park? Many itineraries state that the nature of the visit to Scotland are transitory in nature, with but one or two nights in key tourist locations within a week or two-week tour of the country. Such a finding is perhaps of equal concern to the national tour ism organisation, VisitScotland, in that many visitors are making extensive use of the car to explore the country, staying only fleetingly in individual locations. This analys is confirms the traditional touring itinerary seen in Scotland since the emergence of tourism (Grenier, 2005). As such, Scotland as a whole might be viewed as a touring destination, with no main destination at all, a trip type identified by Opperman (1995). Undeniably, marketing will play a more important role if more hub and spoke style itineraries are to be encouraged, which are likely to have a much more positive economic impact on the area than itineraries that simply transport the visitor from points A to B outside the Park boundaries. 
A similar issue for a National Park Authority relates to the porosity of boundaries. In a wellestablished tourist destination such as Scotland, iconic representations of must-visit places are more likely to influence visitor behaviour and choice of destinations than simply imbuing National Park status. This is clear in the analysis of itineraries, where visitors displaying hub and spoke style itineraries did not always remain within the Park boundaries, but travelled outside on day trips to visit locations within a 50 to 100 miles return radius. Such visits are not necessarily good for the National Park, as such visitor traffic contributes to localised congestion but does little to add to the economy or enrich the visitor experience of the Park on that day. However, hub and spoke itineraries might appear to offer the best potential for policymakers trying to build a sustainable destination, where visitors create positive economic impacts in various locations with in a destination and length of stay creates more opportunities to experience the Park environment and exposure to interpretive material presented by the Park Authority on desirable behaviour and activities.

With a large number of itineraries present without stops that are en route to another destination (mainly on the west coast, and confirming the importance of Argyll, the Western Isles and the western Highlands as a tourist foci), the National Park meets Mill and Morrison's (1985) definition of a secondary destination, that is, one which is an interesting or necessary place to visit on the way to a primary destination. As the popularity of the west coast is unlikely to decline, and accepting that en routers are an inevitable component of visitors to the Park, then attention must turn to marketing, quality and product development issues designed to meet the needs and attentions of this type of traveller (McKercher, 2001), particular those that do make short stops once or twice on their journey. Ensuring that the en route traveller is suitably impressed with the standards of refreshment, toilet, car parking and short walk provision is key, and engendering a relationship with the traveller that might stimulate them to return and spend more time in the area 
at another point is beneficial. While circle tour itin eraries are more likely to create positive economic ben efits and spread these to a number of different locations, suppliers and communities, it should not be assumed that those displaying a circle tour style itinerary are necessarily 'go od' tourists. Further analysis identified that $38 \%$ of those on a circle tour were simply on a drive (with no more than one short stop en route, not overnight). However, some $62 \%$ of circle tours involved multiple stops, and about half of these stayed at least one night. Indeed, recent research by Ryan and $\mathrm{Gu}$ (2007) identifies the location of tourism trips within the growing notion of tourism mobilities (e.g. Hall, 2005a, 2005b) where destinations may be multi-use places and spaces.

Perhaps more idealised itineraries can be encouraged to generate the most appropriate forms of visits to the Park, based on single destination, circle tours with ov ernight stops and hub and spoke style travel, and where a proportion of day trips are taken using alternative forms of transport. While many itineraries included a long walk, fewer than $0.5 \%$ u sed public transport to access destinations while in the National Park. Developing more sustainable forms of transport to access the Park and improve links between recreational opportunities within it is now viewed a strategic priority (LLTNPA, 2005b). Understanding the linkages between locations and the typical patterns of visitors seeking a short circuit, a day visit or ind eed a longer circle itinerary allows a clearer picture of how sustainable transport initiatives that meet the needs of users might be developed.

\subsection{Methodological issues and further research}

While McKercher \& Lew's (2004) identification of the challenges of itinerary-related research are undeniably accurate, researchers can find appropriate mechanisms for gathering data that can assist in understanding itineraries and traffic flows. Map-based questionnaires provide a practical research tool in the absence of major funding to undertake the type of research programme described by Becken et al (2007). The itinerary mapping survey has provided useful results in 
terms of understanding the flow of visitor traffic, and the relative importance of Park locations in terms of visitor numbers. A by-product of the flow mapping was the analysis of routes, stopping points and reasons for stopping. Such data complements that of the National Park Visitor Survey which uses a conventional face to face interview method but is not linked to more complex data capture methods such as GIS. This study complements that Survey by illuminating site linkages, roles, uses and their relative importance. Understanding these issues is fundamental to tourism planning and identifying destinations in the Park. As previously stated this study is only the first stage of a much longer term tracking and analysis of visitors and visitor activity in the LLTNP and will inform a continuing debate by staff on the ground who provided anecdotal evidence about the state of tourism infrastructure at specific locations and current usage in relation to the volume of visitors. GIS is a very helpful tool in taking the concept of itineraries and their mapping into workable outputs for the rational planning of tourist travel and activity in a newly established National Park, so it can begin to develop the policies and plans necessary to meet the objectives set out in the 2000 National Park Act.

\section{Conclusions}

The car is a major force in day tripping and recreational and tourist travel in many National Parks worldwide but to date few studies have been published that model the interactions between tourism, visitor behaviour, the resource base and the potential effects on specific locations. Where such exercises have been undertaken, they are confined to unpublished reports or internal documents that do not get widely disseminated. In the case of LLTNP, the creation of the Park and the desire to understand visitor dynamics and behaviour as a basis for spatially-informed tourism planning provided an opportunity to establish some of the fundamental relationships that exist in tourist transportation within and to the Park. It also helps to show why people visit the

Park, how they use specific locations and the planning needs at a strategic level. As tourism is a 
fundamental activity in the LLNP and is also a major economic activity supporting many communities within the Park, ensuring that to urists and visitors are accommodated and managed in a sustainable manner is a key challenge in the Park Act. The transport element of the Park visit is a useful starting point to begin to question how sustainable transportation to and from the Park is, and to then ask what will the long-term prospects be if car-based travel is forecast to grow. 


\section{References}

Bahaire, T. \& Elliott-White, M. (1999). The application of geographical information systems (GIS) in sustainable tourism planning. Journal of Sustainable Tourism, 7(2): 159-74.

Becken, S. (2005). Towards sustainable transport: An analysis of coach tourism in New Zealand. Tourism Geographies, 7 (1): 23-42.

Becken, S. , Vuletich, S \& Campbell, S. (2007). Developing a GIS-supported tourist flow model for New Zealand. In D. Airey and J. Tribe (Eds.) Cutting edge Tourism, Elsevier. Oxford. Draft manuscript.

Blacks (1894). Blacks Picturesque Guide to the Trossachs. Ed inburgh: Adam \& Charles Black.

Boyd, S. \& Butler, R. (1996). Seeing the forest through the trees: Using GIS to identify potential ecotourism sites in Northern Ontario. In L. Harrison \& W. Husbands (Ed s.), Practising Responsible Tourism: International Case Studies in Tourism Planning, Policy and Development (pp. 380-403). Chichester: Wiley.

Briedenham, J. \& Wickens, E. (2004). 'Tourism routes as a tool for the economic development of rural areas - vibrant hope or impossible dream?', Tourism Management, 25 (1): 71-79.

British Travel Association \& the University of Keele (1967 and 1969). Pilot National Recreation Survey. Keele: British Travel Association and the University of Keele.

Burton, T. (1966). A day in the country: A survey of leisure activity at Box Hill in Surrey. Journal of the Royal Institute of Chartered Surveyors, 98: 378-80.

Butler, R. \& Boyd, S. (2000). Tourism in National Parks. Chichester: Wiley.

Caffyn, A. (2003). The dev elopment of sustainable tourism in the Trossachs, Scotland. In D.Hall \& G.Richards (Eds.), Tourism and Sustainable Commun ity Development (pp. 83-100). London: Routledge,

Campbell, C.K. (1966). An Approach to Recreational Geography, B.C. Occasional Papers No. 7.

Chubb, M. (1989). Tourism patterns and determinants in the Great Lakes region: Population, resources and perceptions. GeoJournal, 19(3): 291-6.

Clawson, M. \& Knetsch, J. (1966). The Economics of Outdoor Recreation. Baltimore, MD: Johns Hopkins University Press.

Cook, T. (1861). Cook's Scottish Tourist Official Directory: A Guide to the System of Tours in Scotland under the Direction of the Principal Railway, Steamboat and Coach Companies. Leicester: Thomas Cook.

Coppock, J.T. \& Duffield, B. (1975). Recreation in the Countryside. London: Macmillan. 
Countryside Agency (2003). Transport in Tomorrow's Countryside. Cheltenham: Countryside Agency.

Countryside Commission (1992). Trends in Transport and the Countryside. Cheltenham: Countryside Commission.

Countryside Commission (1994). All Parks Survey. Cheltenham: Countryside Commission.

Department for Transport, Local Government \& The Regions (2001). Transport Statistics Bulletin, National Travel Survey. Norwich: The Stationery Office.

Dickinson, J., Calver, S., Watters, K. \& Wilks, K. (2004). Journ eys to heritage attractions in the UK: A case study of National Trust visitors in the south west. Journal of Transport Geography, 12: 103-13.

Durie, A. (2003). Scotland for the Holidays: A History of Tourism in Scotland 1780-1939. East Linton: Tuckwell.

Eaton, B. \& Holding, D. (1996). The evaluation of public transport alternatives to the car in British national parks. Journal of Transport Geography, 4(1): 55-65.

Eby, D. \& Molnar, L. (2000). Importance of scenic byways in route choice: A survey of driving in the United States. Transportation Research A, 95-106.

Elliott-White, M. \& Finn, M. (1998). Growing in sophistication: The application of GIS in postmodern marketing. Journal of Travel and Tourism Marketing, 7(1): 65-84.

Forer, P.C. \& Pearce, D.G. (1984). Spatial patterns of package tourism in New Zealand. New Zealand Geographer, 40(1): 34-42.

Forer, P. \& Simmons, D. (2002). Serial Experiences: Monitoring, Modelling and Visualising the Free Independent Traveller in New Zealand at Multiple scales with GIS. In A. Arnberger, C. Brandenberg \& A. Muhar (Eds), Monitoring and Management of Visitors Flows in Recreational and Protected Areas (173-180), Vienna: Institute of Landscape Architecture and Landscape Management, Bodenkulture University.

Glyptis, S. (1981). People at play in the countryside. Geography, 66(4): 277-85.

Gold, J. \& Gold, M. (1995). Imagining Scotland: Tradition, Representation and Promotion in Scottish Tourism Since 1750. Aldershot: Scolar.

Grenier, K. (2005). Tourism and Identity in Scotland 1790-1914: Creating Caledonia. Ald ershot: Ashgate.

Gunn, C. \& Var, T. (2002). Tourism Planning: Basics, Concepts, Cases. London: Routledge, $4^{\text {th }}$ edition.

Hall, C.M. \& Page, S.J. (2006). The Geography of Tourism and Recreation. London: Routledge, $3^{\text {rd }}$ edition. 
Hardy, A. (2003). An investigation into the key factors necessary for the development of iconic tourisng routes. Journal of Vacation Marketing, 9 (4): 314-330.

Huang, B., Yao, L. and Raguraman, K. (2006). Bi-level GA and GIS for multi-object TSP route planning, Transport Planning and Technology 29 (2): 105-124.

Klisky, A. (2000). Recreation terrain suitability mapping: A spatially explic it methodology for determining recreation potential for resource use assessment. Landscape and Urban Planning, 52 (1): 33-43.

Loch Lomond \& The Trossachs National Park Authority (2004) Visitor Destination Study, Balloch: LLTNPA.

Loch Lomond \& The Trossachs National Park Authority (2005a). State of the Park Report. Balloch: LLTNPA.

Loch Lomond \& The Trossachs National Park Authority (2005b). National Park Plan 2005 Consultative Draft. Balloch: LLTNPA.

Lew, A, \& McKercher, B. (2002). Trip destinations, gateways and itineraries: The example of Hong Kong. Tourism Management, 23 (6): 609-621.

Lue, C., Vrompton, J. \& Fesenmaier, D. (1993). Conceptualisation of multi-destination pleasure trips. Annals of Tourism Research, 20: 289-301.

McKercher, B. (2001). A comparison of main destination visotrs and through travelers at a dualpurpose destination. Journal of Travel Research, 39: 433-441.

McKercher, B. \& Lew, A. (2004). Tourist flows and the spatial distribution of tourists. In A. Lew, C.M. Hall \& A. Williams (Eds.), A Companion of Tourism (pp. 36-43). Oxford: Blackwell.

Mings, R. \& McHugh, K. (1992). The spatial configuration of travel to Yellowstone National Park. Journal of Travel Research, 30: 38-46.

Opperman, M. (1995). A model of travel itineraries. Journal of Travel Research, 33 (4): 57-61.

Page, S.J. (1994). Transport for Tourism. London: Routledge.

Page, S.J. (2003). Tourism Management: Managing for Change. Oxford: Butterworth-Heinemann.

Page, S.J. (2005). Transport and Tourism: Global Perspectives. Harlow: Pearson, $2^{\text {nd }}$ edition.

Patmore, J.A. (1971). Routeways and recreation. In P. Lavery (Ed.), Recreational Geography (pp. 70-96). Newton Abbot: David and Charles.

Ryan, C. and Gu, H. (2007). Spatial planning, mobilities and culture - Chinese and New Zealand student differences for Californian travel', International Journal of Tourism Research 9. In press.

Scottish Executive (2006). Tourism Framework for Change, Edinburgh: Scottish Executive. 
Scottish Parliament (2000). National Parks (Scotland) Act 2000. London: HMSO.

Suna, Y. \& Lyndon, L. (2004). Agent-based personalised tourist route advice system, XXth ISPRS Congress, Geo-Imagery Bridging Continents, 12-13 July, Istanbul. Turkey. http://www.isprs.org

Taplin, J. \& Qiu, M. (1997). Car trip attraction and route choice in Australia. Annals of Tourism Research, 24(3): 624-37.

Transport for Leisure Ltd. \& Smith,R. (2001). Transport, Tourism and the Environment in Scotland. Edinburgh: Scottish Natural Heritage.

VisitScotland (2006). Tourism in Scotland 2005. Edinburgh: VisitScotland.

Wager, J. (1967). Outdoor recreation on common land. Journal of the Town Planning Institute, 53: $398-403$.

Wall, G. (1971). Car owners and holiday activities. In P. Lavery (Ed.), Recreational Geography, Newton Abbot: David \& Charles.

Wall, G. (1972). Socioeconomic variations in pleasure trip patterns: The case of Hull car owners. Transactions of the Institute of British Geographers, 57: 45-58.

Woo \& Page, S.J. (2002). Tourism demand in East Asia Pacific: The case of the South Korean outbound market and activity patterns in New Zealand. In C.M.Hall \& S.J.Page, The Geography of Tourism and Recreation (pp. 78-84). London: Routledge, 2nd edition.

Zacharias, J. (2006). Exploratory spatial behaviour in real and virtual environments, Landscape and Urban Planing 78, (1/2): 1-13.

Submitted September 2006; Revised Manuscript March 2007 